\title{
Talking About North American Intellectual Tradition, Free Speech and Education with Camille Paglia
}

Interviewer: Gunter $\mathrm{Axt}^{1}$

Submetido em 23 e aprovado em 26 de dezembro de 2018.

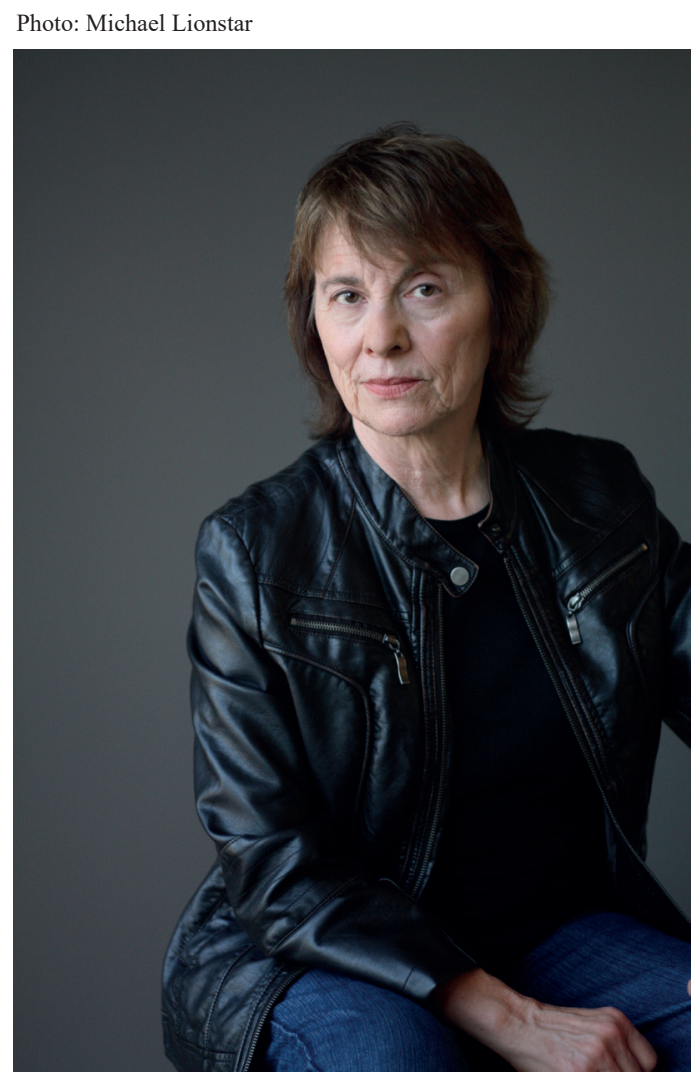

\section{Introduction}

Camille Paglia is the University Professor of Humanities and Media Studies at the University of the Arts in Philadelphia, where she has taught since 1984. She received her 
B.A. from the State University of New York at Binghamton in 1968 and her M.Phil. and Ph.D. degrees from Yale University in 1971 and 1974 respectively.

Her prior books are: Sexual Personae: Art and Decadence from Nefertiti to Emily Dickinson (1990); Sex, Art, and American Culture (1992); Vamps \& Tramps: New Essays (1994); The Birds, a study of Alfred Hitchcock published in 1998 by the British Film Institute in its Film Classics Series; Break, Blow, Burn: Camille Paglia Reads Forty-Three of the World's Best Poems (2005), Glittering Images: A Journey through Art from Egypt to Star Wars (2012), and Free Women, Free Men: Sex, Gender, Feminism (2017). Her eighth book, Provocations: Collected Essays, was released by Pantheon in October 2018.

Prof. Paglia was a co-founding contributor and columnist for Salon.com, beginning with its debut issue in 1995. She has written numerous articles on art, literature, popular culture, feminism, education, religion, and politics for publications around the world.

In this interview, conducted by e-mail between December 14 and 22, 2018, Camille Paglia talks to Gunter Axt about North American intellectual tradition and some of her main theoretical references, such as media theorist Marshall McLuhan. the American literary critics Leslie Fiedler and Norman O. Brown, as well as Northrop Frye, Erving Goffman and Erich Neumann. She also discusses Marxism, Post-structuralism, Simone de Beauvoir's and Arnold Hauser's legacy. The interview also addresses the so-called Queer Theory, political correctness, and the movement of Free Speech in universities. She comments about her meeting with Jordan Peterson and her impressions of his ideas. Finally, Camille talks about her impressions of the recent academic scandal involving scholars Judith Butler and Avital Ronell, in the United States. 


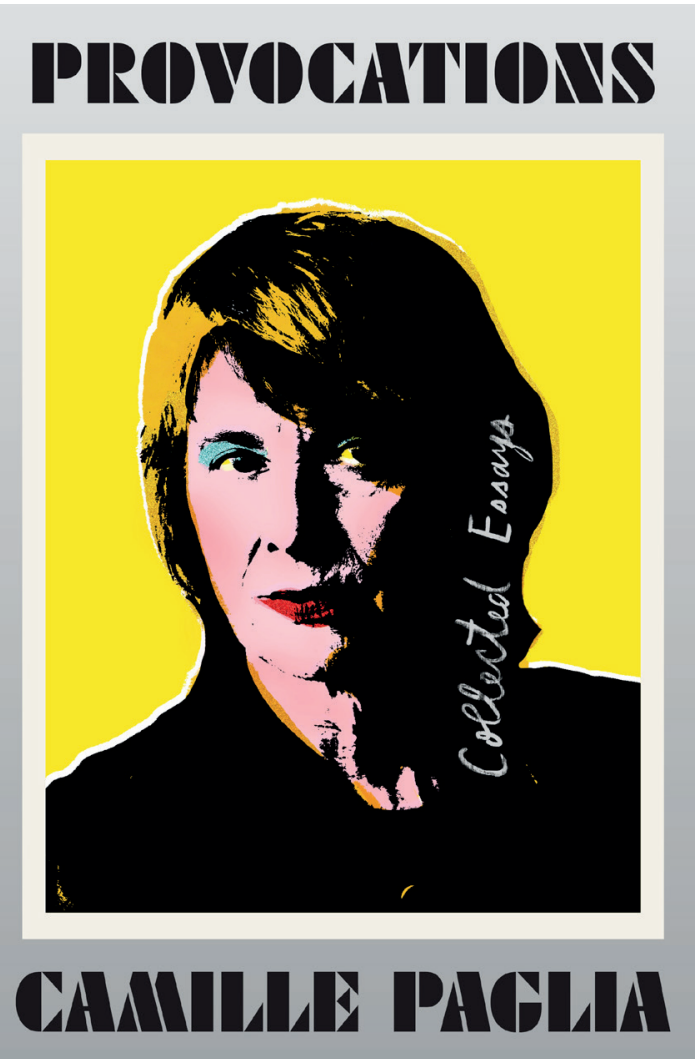

Gunter Axt - In a lecture at Fordham University in 2000, published in the online version of the journal Interfaces Brazil / Canada in 2012, and now appearing in your new collection of essays (Provocations), you defend the existence of a North American intellectual tradition, established in the 1950s and 1960s, and the need to return to it. In your opinion, what constitutes this tradition, and why are the authors that integrate it not being properly valued now?

Camille Paglia - In my view, North American culture has always been profoundly grounded in nature, from the tribal Native American epoch through European contact 
and settlement. Both the U.S. and Canada cover an enormous distance of thousands of miles, incorporating an astounding range of physical features, including towering mountain ranges and dense forests. Most North Americans instinctively understand the High Romantic theme of the "sublime" - a nearly religious vision of the enormity of the universe and its awe-inspiring power, dwarfing humanity and its fragile constructions.

Canada stretches north to the vast frozen tundra of the Arctic Archipelago, while the U.S. is annually struck by massive hurricanes and terrifying tornadoes. The titanic force of nature has been a North American theme from Herman Melville's Moby-Dick (1851) to Hollywood's epic disaster movies, based on actual historical events, such as the destruction of Chicago by fire (1871) or San Francisco by an earthquake (1906).

The folly of post-structuralism, as it has become embedded in North American academe since the late 1970s, is that it represents a puny and contracted view of human existence. Post-structuralism was produced by French-speaking Europeans whose quarrel was with the heavy rationalist legacy of Descartes, as well as the neoclassical Racine, still lingering in their language and high culture. It is absurd that that provincial argument was transplanted wholesale to North America, where it is utterly pointless. Except for a narrow band of the French Alps, the French occupy a perennially temperate zone of few weather extremes. Aside from Delacroix's fiery Romantic tableaux, the French have rarely experienced or understood the magnitude or ferocity of nature.

In "The North American Intellectual Tradition", I argued that pragmatism, based on observation of concrete physical reality, including the brute operations of nature as well as intricate social behavior, is the essence of North American thought. The Canadian media theorist Marshall McLuhan and the American literary critics Leslie Fiedler and Norman O. Brown (both psychoanalytic in approach) were deeply knowledgeable about ancient and modern literature and also intuitively understood art and the creative process.

Jacques Lacan, Jacques Derrida, and Michel Foucault were cynical gameplayers whose approach to art was manipulative, mechanistic, and destructive. They were waging a local war: to demolish the arrogant pretensions of insular, elite French 
culture. That has nothing whatever to do with us in North or South America! Far from being oppressed by an antiquated high culture that requires ruthless deconstruction, the young are drowning in an omnipresent, now often mediocre and derivative popular culture. Furthermore, they are currently victimized by a banal, politically correct educational curriculum that denies them knowledge of the totality of human history, with its eternal war between civilization and barbarism. Contrary to current cant, the West did not invent imperialism or racial injustice.

When will the endless, empty clichés of post-structuralism end?

GA - How important is Marshall McLuhan to better understand the mass culture of the second half of the twentieth century and now? Why could McLuhan be more useful to this task than authors of the Frankfurt School or French poststructuralists? Do you believe that there could be some influence of the milieu--especially the province of Manitoba and later the University of Toronto--in the formation of McLuhan's critical personality?

$\mathrm{CP}$ - Marshall McLuhan had an instinctive understanding of mass media, which he interpreted in sensory terms as an extension of the human body. This brilliant perception was a superb illustration of North American pragmatism, grounded in the concrete world. In analyzing media, McLuhan used improvisational techniques of aphorism, pun, satire, and collage. He caught the restless, mercurial spirit of mass media, which changes from hour to hour like sunlight reflected in the sea.

With its puritanical Marxist preconceptions, the Frankfurt School has always been incapable of responding to the energy and vitality of popular culture, which arose as a direct expression of popular taste in the first mass-market urban newspapers of the $1830 \mathrm{~s}$. Its dreary, humorless jargon (such as the clunky, ubiquitous "commodification") simply exposes the snobbery of the Frankfurt School, which pretends sympathy for the masses while exposing its contempt for their debased taste. The aesthetic judgments of Frankfurt theorists are actually tediously bourgeois, no different than the prissy scorn of 1950s middlebrow critics for Hollywood movies and rock ' $n$ ' roll - pop genres that are now thankfully acclaimed as major modern art forms. 
The ponderous discourse of the Frankfurt School, rooted in the 1930s even before the rise of commercial television, is hopelessly dated. Andy Warhol, one of my major influences, rescued and redeemed pop culture from its attackers in his luminous polychrome transcriptions of advertisements, grocery store products, tabloid newspapers, and Hollywood publicity photographs. The Frankfurt School was nullified and rendered obsolete by Pop Art, which exploded in the early 1960s and dominated the decade. But of course a host of careerist academics did not get the message and have continued to drag the now stinking Frankfurt corpse around their groupthink campuses.

As for the evolution of McLuhan's thought, it would be interesting to explore what impact the University of Manitoba had on McLuhan when he was an undergraduate. I have seen some minimal discussion of the competitive atmosphere of the University of Toronto when McLuhan as a professor was vying with the myth-critic Northrop Frye, his rival in fame who was disdainful of popular culture. That McLuhan was born in distant Alberta, far from Canada's historic culture centers, always struck me as highly meaningful: I too, born in the Snow Belt of upstate New York, have always felt like an outlander, never comfortable in cities but still constantly monitoring their voices via the great populist medium of static-prone AM radio.

GA - You have criticized Marxism in many of your essays - as in the first few paragraphs of the essay Women and Law, published as a preface to a work I organized in Brazil and which is now reprinted in Provocations, or in the Introduction to Glittering Images (where you say Marxism lacks psychology and metaphysics). But at the same time you celebrate the work of authors such as Simone de Beauvoir and Arnold Hauser. What is the difference? What do you mean by neo-Marxism or cultural Marxism?

CP - The Social History of Art (1951), a multi-volumed epic by the deeply erudite Marxist scholar Arnold Hauser, had a huge influence on me in my private research during graduate school. Hauser demonstrated how analysis of art can be grounded in sociology and economics without losing respect for the artist or art work. Too many academic books of cultural Marxism (by which I mean books by humanities professors simplistically adopting Marxist formulas without wider study of history or political science) are 
coarsely reductive, stripping spiritual meanings out of art and reducing the art work to a sterile consumer object with a price tag - which is only one of the many attributes of art throughout world history. It is no accident that I have spent most of my 47 years of teaching at small art schools, where I have had a very close view of the authentic process of artistic aspiration, creation, and expression.

Simone de Beauvoir's magnum opus, The Second Sex (1949), had a tremendous impact on me in high school: a Belgian woman colleague of my father gave it to me for my sixteenth birthday. I loved De Beauvoir's steely, unsentimental survey of history and her remorselessly precise dissection of woman's evolving social status. For example, she argued that the privileged, aristocratic chatelaine of medieval palaces was actually a prisoner of her high caste, with less freedom of movement or exposure to experience than women serfs at work in the fields.

I was already attuned to class consciousness from my own family history. All four of my grandparents plus my mother were born in Italy and were immigrants escaping the crushing rural poverty of the motherland. I was born in the small, remote, upstate town of Endicott, New York, to which thousands of immigrants came to work in the EndicottJohnson shoe factories. My maternal grandfather operated a leather-stretching machine at the factory, while my paternal grandfather was a barber. Because of the G.I. Bill, my father, who had been an Army paratrooper during World War Two, was the first and only member of his large, blended family to go to college (after my parents were married and I was already born). He became a high-school teacher and eventually a professor at a Jesuit college. Hence, I have had unusually direct personal experience of the major historical transitions in social class, from small farmers of the agrarian era through the industrial proletariat to the professional middle class.

Marxist analysis has become rigidly formulaic and outdated. The concepts of class solidarity and class warfare may have been pertinent to the nineteenth and early-twentieth centuries, during the heroic period of the nascent labor movement, which pressed for unionization and collective bargaining. But manufacturing has dwindled in the U.S., as elsewhere in the developed world, due to the corporate flight overseas to sources of 
cheap labor in the Third World, where exploited workers are geographically scattered and unable to gather and unionize.

It should be blatantly obvious that, except for a thin layer of entrenched poverty in inner cities and mountain regions, the U.S. presently consists of a gigantic middle class with many gradations of income, as well as education and core values. I see multiple fine strata within that swollen group (from lower middle class to upper middle class) which conventional Marxist analysis does not perceive or adequately interpret. Car ownership as well as televisions, computers, and cell phones are now widespread in urban neighborhoods that were once considered poor.

Far from this sprawling system being a fatalistic incubator for apocalyptic class warfare, virtually everyone simply wants to raise the family income and general comfort level. Entrepreneurs turned multi-millionaire (Silicon Valley whiz kids like Steve Jobs and Bill Gates or urban rappers like Jay-Z) are viewed as enviable role models and not callous robber barons. Over the past two centuries, capitalism has enormously raised the standard of living in the developed world and is singlehandedly responsible for the emancipation of women, who can now support themselves and no longer must depend on father or husband for survival.

However, capitalism, like every other economic system, has its intrinsic problems and flaws. Its volatility makes it prone to inflation or depression, which democratic governments and agencies correctly monitor and (with prudent moderation) regulate. A principle of political oversight and reform must be built into capitalism: an unfettered free market puts too many at risk. It took decades during the early nineteenth century for the British government to establish a principle of public interest and authority in forcing private property owners to protect workers from dangerous or unhealthy conditions as well as cruelly excess hours and low wages. The abolition of child labor was a great humanitarian cause that took an outrageously long time to achieve.

The issue of economic inequities under capitalism seems over-emphasized to me, because I am so admiring of the cultural institutions (museums, libraries, opera houses) funded by the tycoons of the Gilded Age, such as Andrew Carnegie. The great 
mansions and gardens of the nouveau riche Philadelphia Main Line elite in the latenineteenth and early-twentieth centuries were constructed and furnished, in many cases, by Italian immigrants, whose virtuoso workmanship remains a splendor of American art. I have a treasured garden ornament - a stone gate cap carved in scallop shape-which I rescued from the overgrown and decayed grounds of a Victorian mansion in Vermont, where I was teaching in the 1970s. It is obviously from the virtuoso hand of an Italian, whose arrival in America was made possible by capitalist enterprise in its most lawless days.

But today, great wealth can be amassed not by providing society with a beneficial new service or invention but by conspiratorial manipulation of the financial services sector, amoral practices that have become epidemic on Wall Street over the past 40 years. The Clintons were notorious for their intimacy with and political protection of that corrupt world, with its gluttonous insider trading - which is why I voted for Bernie Sanders in the 2016 presidential primaries (and for Jill Stein of the Green Party in the national election). Among other things, the Democratic party has been feeble or misguided in its failure to stop the takeover and consolidation of local banks into a massive nationwide system that has become almost impossible to reform.

The best in socialist thinking has already been adopted by the U.S. in its establishment of an income tax in 1913, as well as the Social Security program, signed into law by Franklin Delano Roosevelt in 1935, which provides support and sustenance for the elderly. However, Marxism has been wrong about too many things, as demonstrated by the dictatorship and mass butchery of Joseph Stalin and Mao Tse Tung. Collectivism destroys freedom of thought and individual initiative. Central planning requires a grotesque expansion of bureaucracy and an authoritarian over-control that stifle innovation and lead to stagnation and paralysis.

Yes, I have repeatedly written about the absence in Marxism of a metaphysics as well as a coherent psychology. Marxism is obsessed with society and does not recognize the existence of nature - including human nature. To believe that human beings act only for material reasons - to enlarge their power or wealth - is a gross libel. Furthermore, 
the proletariat has never behaved as Marxists predicted. Globalism is the fantasy of a bourgeois elite, while the working class remains strongly patriotic and pro-military. Indeed, it is the fashionable diluted Marxism of the mainstream media that has prevented them from foreseeing or understanding the rise of Donald Trump in the U.S. and Jair Bolsonaro in Brazil.

GA - What is your opinion about the current legacy of Northrop Frye's work? You do not include him in your perspective of The North American Intellectual Tradition, but your dissertation advisor at Yale, Harold Bloom, celebrated Anatomy of Criticism as one of the most important books of Western criticism.

$\mathrm{CP}$ - Northrop Frye was a titanic figure during my college and graduate school years, and it is shocking how swiftly his work was swept away by the influx of post-structuralism. In retrospect, Frye certainly represented the high water mark of literary criticism in the mid-twentieth century. I mentioned him in passing in "The North American Intellectual Tradition", but I did not include him because he was not a social theorist per se: he treated literature as a self-enclosed system whose only precursor was religion.

Frye set a dazzlingly high standard for true scholarship, a profound learning that suffused every paragraph he wrote. His prose style was supple, lucid, and urbane, with none of the pretentious obscurantism that now mars so many academic books. Frye's synoptic myth-criticism descends from Carl Jung and ultimately from Sir James George Frazer's The Golden Bough (1890-1915), which inspired major modernists from William Butler Yeats and T.S. Eliot to James Joyce and D.H. Lawrence.

Although I too am a myth-critic, I was somewhat impatient and dissatisfied in college with what I sensed was a palpable repression or censorship in Frye's work. That is, even though alternately fertile and wintry nature is encompassed in his theory of genres, both sex and horror (which are abundantly present in Frazer's speculative anthropology) seem to have been sanitized and purged from Frye's system. I sensed a certain prim puritanism, a residue of Frye's Methodist lineage (his grandfather was a preacher in Ontario and Quebec). But any future revival of genuine literary criticism must certainly begin by recovering and restoring the entire towering oeuvre of Northrop Frye to the undergraduate and graduate curriculum. 
Unlike his polemical Toronto colleague, Marshall McLuhan, Frye seemed rather unworldly and recessive. In 1969, my second year of graduate school, Frye came to Yale to give the Grey Lecture, entitled "Pure and Applied Imagination". One of my fellow women graduate students (a descendant of the legendary Yale professor, William Lyon Phelps) was selected to dine with Frye and his wife at the official dinner, during which he said not a single word. At the end, Mrs. Frye leaned over and said apologetically, "Northrop is very shy" - to which my frustrated friend replied, "Well, I'm shy too!"

GA - Would you include Erving Goffman in the context of this tradition? How did his ideas influence your work? Suddenly, it looks like the idea of "gender as performance" is being promoted as a great novelty by Queer Theory, but your reflections already identify the presence of this concept in Goffman. Incidentally, what's really new in gender's current "performance"? In the passage from the 1960s to the 1970s, we had Diane Arbus, Mick Jagger, David Bowie, and Robert Mapplethorpe, for example. In Brazil we had the Secos \& Molhados and the Dzi Croquettes. In your new book, there is an extraordinary essay on Bowie, originally the catalog text of the big 2013 exhibition of Bowie's costumes at the Victoria \& Albert Museum in London.

CP - Erving Goffman's The Presentation of Self in Everyday Life (1956; rev. ed.,1959) had enormous prominence and visibility in the 1960s, when the counterculture was at its height. The book was a major statement about the performative nature of personality and social behavior, flowing directly from the powerful tradition of social psychology in the U.S. since the 1920s. It is completely ridiculous that naive humanities academics continue to credit Michel Foucault (who heavily borrowed from Goffman without attribution) or the Foucault-worshiping Judith Butler for Goffman's penetrating insights, which were tremendously useful to me as I was assembling the materials for my Yale doctoral dissertation, titled Sexual Personae: Categories of the Androgyne.

When I wrote "The North American Intellectual Tradition” for Fordham University in 2000, I knew nothing whatever about Goffman's life except that he had concluded his career as a chaired professor at the University of Pennsylvania. Only later did I discover to my astonishment that he was Canadian: he was born in Alberta (that persistent theme!) 
and attended the University of Manitoba and the University of Toronto - more evidence for my theory about the nature-born pragmatism and power of social observation of North American thinkers.

You are absolutely correct to question the derivativeness of today's queer theorists, who appear to lack basic research skills to trace the origins of their own ideas. Mick Jagger (with Anita Pallenberg, Keith Richards' decadent lover) starred in Nicolas Roeg's 1970 film, Performance, whose famous gender-bending advertising poster showed Jagger in a feminine coiffure, lipstick, and mascara. In college, I had been electrified by Andy Warhol's short film, Harlot (1964), where Mario Montez in a blonde wig simulated a classic Hollywood sex-bomb, slowly peeling a banana and sensuously devouring it.

The Coquettes, a radical hippie theater group founded in 1969 in San Francisco's Haight-Ashbury district, played with carnivalesque transvestite fantasy and open homoeroticism. Charles Pierce, whom I was lucky enough to see perform in New York in 1975, had been doing brilliantly satirical drag impersonations of great women stars in theaters and gay clubs since the 1950s.

In Luchino Visconti’s 1969 Nazi-era film, The Damned, Helmut Berger did a drag parody of Marlene Dietrich in The Blue Angel that had an enormous impact on the birth of glam rock in the U.K. David Bowie, about whom I wrote "Theater of Gender" (the V\&A catalog essay), was one of the principal creators of the new genre of "performance art", which would flourish from the 1970s through the 1990s. Foucault is flat, boring, and superfluous - all you need is Bowie!

Historically, these fluid gender themes can be traced back from Pop Art to Dada and Surrealism, when Marcel Duchamp posed for the camera as his female alter ego, Rrose Sélavy, and when the 1938 Surrealist Exhibition in Paris featured a Rue des Mannequins - a corridor of plaster department-store dummies impudently bedecked with pornographic and cross-dressing motifs.

GA - In Brazil we are living in a controversial moment, in which a bill project called "School without a Party" is discussed and that aims to guarantee the impartiality 
of teachers in the classroom, not only from the partisan point of view, but also theoretical and ideological. Critics of this bill project say that ideological guidance of any kind is not settled by law and that such a law would open the door to censorship as well as the introduction of unscientific theories such as creationism and intelligent design. Do you think it is possible for a historian to be impartial? Would you tell the Nazi perspective in the classroom, for example, as a counterpoint to the view of the winners of World War Two? Are there humanistic consensus above the right to the contradictory? On the other hand, is there a possible balance? How can we foster an environment of free thought in classrooms that promotes tolerance and diversity?

$\mathrm{CP}$-As a career college teacher, I would always oppose any intrusion of government - local, state, or national - into academic deliberation and procedure. However, I have been horrified over the past 40 years by the slide of liberal professors into unapologetic ideological advocacy in the classroom. This trend is ethically wrong and professionally irresponsible, a betrayal of our basic vocational principles. The classroom is a laboratory for detached, objective thought and the acquisition of knowledge; it is not an arena for social welfare experiments or personal activism.

In my view, the teacher must regularly inform the class that every student has the right to his or her opinions on any issue, not matter how contested or controversial, and that there is no "party line", promulgated and enforced by the teacher. I do this even in my "Lyric Poetry" class, where I must be totally honest about my bias for the Beat school of street-language poetry and my rejection of the currently most celebrated American poets, such as John Ashbery and Jorie Graham, whom I regard as bombastic poseurs.

One of my formative intellectual experiences was reading the first required book in my large basic biology lecture course in college: a survey of the Pre-Socratic philosophers. We were being introduced to successive theories about the origins of the cosmos, beginning in religious myth and culminating in the invention and refinement of the scientific method. This was a sensational way to teach, and I have never forgotten it.

Hence I fail to see what is wrong with asking biology teachers to present, however briefly, alternate views and models of cosmology, above all theories with ongoing 
contemporary impact, such as creationism and intelligent design. Surely it is important to identify and evaluate any lingering objections to Darwin's theory of evolution, including what many Christians feel is contradictory evidence. Students deserve to hear every aspect of major contemporary debates: to suppress the arguments is to treat science like settled dogma. But science should properly be in a constant process of inquiry and dynamic revision.

As for the "Nazi perspective" on World War Two, I cannot imagine how it is possible to talk about or even summarize that terrible war (as I frequently must do in teaching twentieth-century culture) without explaining precisely that: the humiliation of Germany's defeat in World War One; the collapse of the German economy in the 1920s; Hitler's rise through messianic appeals to medieval German identity, refracted through Wagner; the scapegoating of Jews in the Nazi obsession with racial purity; the evocation of Greek idealism being transmitted by torch fire to Berlin at the start of Leni Riefenstahl's Olympia.

In short, it is in the best interests of education to present all possible views of every controversial issue. If teachers shrink from that obligation, we are simply driving students to explore alternative claims on the Web, which has increasingly become a morass of hysterical opinion, factual errors, and outright hallucination.

GA - Since we have mentioned Queer Theory, which has Judith Butler as its most prominent pope, I ask how you followed the scandal, detonated in June 2018, by the publication (in the philosopher Brian Leiter's blog) of a letter, apparently written by Butler, and with signatures from a long list of leading literary critics, giving unrestricted support for Avital Ronell (the New York University theorist and Butler's longtime friend), then charged with sexual harassment of an openly gay doctoral candidate. What has this scandal meant to these prominent figures of literary criticism, and what does it represent, above all, for the American university model, for the politically correct in general, and for mass feminist movements like \#MeToo?

CP - The Avital Ronell scandal was a major bombshell that exposed the arrogance and corruption of high-level U.S. academe. The repercussions will go on for years. 
The U.S. media, in this period of successive \#MeToo revelations, was fascinated by the unusual spectacle of a woman authority figure (a famous professor) being charged with sexual harassment by a male subordinate (a graduate student). However, the real importance of this episode is that, for the first time, the public glimpsed the ruthless careerism, cronyism, and hypocrisy that have been operating for decades behind the façade of academic leftism.

Both Ronell and her longtime close friend and ally, Judith Butler, are products of the “star" system, which arose in U.S. academe in the 1970s and '80s with the arrival of poststructuralism. Professors allegedly committed to liberal and progressive principles invited and incited bidding wars by the foolish, publicity-seeking administrators of major universities, which drove up the salaries of top "theorists" to astronomical heights. The leading leftist professors in the U.S. are now multi-millionaires many times over - when students are crippled by outrageous tuition costs and when low-paid adjunct teachers lacking health benefits are struggling for survival. Graduate students in the humanities are being forced out of the profession because of dwindling jobs: post-structuralism, with its elitist gibberish and strident politics, has destroyed the prestige and relevance of the humanities in the U.S.

Ronell is a narcissistic, babbling mediocrity who obtained her lofty position at New York University because of her early personal association with Jacques Derrida. Although the media calls her a professor of philosophy, her academic degrees are in comparative literature, specifically German studies. On the basis of news reports, Ronell has evidently been notorious for years at N.Y.U. for demanding a cult-like adoration from graduate students, who were expected to instantly respond to emotional personal messages and to visit her home at odd and unprofessional hours.

Butler's rise was also expedited by the incestuous, trend-chasing chaos of comparative literature departments since the 1970s. Her academic degrees are in philosophy, but as I have repeatedly stated over the years, Butler's publishing writing shows little evidence that she has done the kind of basic reading in history, anthropology, psychology, and (above all) biology that we should certainly expect from a theorist of gender. The vanity and vapidity of Butler and Ronell are on full display in a YouTube 
video of the two of them childishly dancing onto the stage of the Pompidou Centre in Paris several years ago. Their tasteless abuse of a classic Aretha Franklin song with their habitual smug irony is only one of the embarrassments here.

GA - A disturbing debate erupted at Yale in 2015 about potentially racist and offensive content to minorities of Halloween customs (like turbans, black faces, witches, gnomes, King Kong, and even Disney characters). What do you think? Can carnival, as a moment of party and joy, fun and symbolic inversion of hierarchies, be regulated by the politically correct?

CP - The attempted a priori censorship of Halloween by a woman administrator at Yale demonstrated the depths to which college education has sunk in the U.S. Ivy League students were being treated like children in kindergarten. Yet instead of indignantly fighting back and telling the administration to stay the hell out of their personal lives, the students wholeheartedly endorsed this paternalistic intrusion and in effect demanded more of it. If this is truly the trajectory of the younger generation, I fear for the future of independent thought.

Halloween, originally a pagan festival of the dead, was my favorite holiday throughout the stiflingly conventional 1950s. It offered a fantastic opportunity to enact one's repressed and forbidden self - which in my case was male. At my first Halloween as a tiny child, I dressed as Lewis Carroll's Alice (in a yarn wig made by my mother) - I was obsessed with both of the Alice books. But after that, my costumes were always transgender, which was virtually unheard of at that conformist time, when sex rules were rigidly polarized and when girls were expected to be feminine and compliant.

My lavish Halloween outfits were sewn and constructed by my ingenious parents, following pictures that I found in magazines or their opera guide. At age five, I was Robin Hood; at six, the toreador from Carmen; at seven, a Roman soldier (based on the Stations of the Cross at church - I ignored Jesus and focused on his tormentors); at eight, Napoleon (from magazine advertisements for Napoleon brandy); at nine, Hamlet (from a Classics Illustrated comic book of the play). A photo taken by my father of me as Napoleon has been reprinted in Provocations. 
It shocks me that the forces of political correctness, with a sanctimonious confidence in their own virtue, believe that they have the right to determine what is or is not "offensive" and to impose their aggressive code of humanitarian propriety upon the world. This is the kind of Pharisaical self-righteousess that Oscar Wilde attacked in Victorian philanthropists. The ancient tradition of carnival masquerade has taken a thousand forms throughout world history. Dionysian holidays permit the release and theatrical expression of anarchic energies erupting from the dark unconscious of mankind.

"Transgressive" was once a favorite epithet of chi-chi academic theorists. What could be more transgressive than Halloween or carnival? We must not permit the spectacular, dreamlike realm of imagination to be policed by moralists of either the Left or the Right.

GA - In April 2016, you gave a lecture at Drexel University on free speech and the modern campus, which resonated greatly, being published in several countries, as in Portugal, England, and Norway. (It is reprinted in your new book.) Were you surprised by this international response? Why exactly do you think free expression is threatened in the contemporary university environment?

CP - Yes, I was surprised and gratified by the wide response to my Drexel lecture. I believe what that unexpected reception demonstrates is a dawning realization by many of the spiritual cost of excessive bureaucratic control of society - on campus or in the workplace.

Administrators were once a relatively small cadre of facilitators in universities, where the faculty determined all important policy matters. But as college attendance has slowly become the norm for middle-class young people, the size and complexity of university operations have grown exponentially, and the faculty have gradually lost power. In the U.S., colleges competing for applicants have added on all sorts of amenities and student services, from single bedrooms to luxurious exercise facilities. Universities are now more like commercial resorts, geared to customer service. 
My own longstanding view is that free thought and free speech should be the non-negotiable heart of every university. As I say in the Introduction to Provocations, free thought and free speech must be elevated over all other values, including material considerations of wealth, status, or physical well-being. Any university that fails to defend free thought and free speech has ceased to be a university and has become nothing more than a recreational corral for pampered adolescents.

GA - In 2017, you had a meeting with the Canadian intellectual Jordan Peterson at the University of Arts in Philadelphia. A video made of that dialogue has viralized on YouTube. You both share, for example, a common interest in Erich Neumann and his work on Jungian myths. Recently, the New York Times has published a profile of Peterson, suggesting him to be a venal, superficial and Far Right character. How do you perceive Peterson's system of thought and his crusade against the politically correct?

CP - Every media article that I have seen thus far about Jordan Peterson has been either too narrow or totally stupid. Many of today's journalists have had an elite education, whose glaring deficiencies are certainly on display in their feeble attempts to interpret or even to describe Peterson's arguments. Far from being a figure of the Far Right, Peterson is a classical liberal who believes in the power and prerogatives of the individual, exactly as I do. I have yet to see a single sentence by Peterson that I disagree with.

It was stunning to discover (on my book tour for Free Women, Free Men in March 2017) this major Canadian thinker who had been as deeply influenced by the Jungian analyst Erich Neumann as I had been. Indeed, we were strangely drawn to exactly the same book - Neumann's The Origins and History of Consciousness (1949). (My 2006 lecture on Neumann at New York University is reprinted in Provocations.) Peterson and I must be viewed as parallel figures, warriors in the campaign to drive nihilistic poststructuralism out of the universities and to recover the humanistic Jung and those he profoundly influenced, including Northrop Frye. Jung remains everywhere in the global, multicultural, and environmentalist New Age movement, which he helped inspire. It is only the universities that remain willfully cynical and barren. 
As for my meeting with Peterson in Philadelphia (in September 2017): as I have publicly said, he was one of the most brilliant minds I have ever encountered. Not only does Peterson possess reasoning powers of the very highest level, but he has that virtuosity of social observation that I have celebrated as the supreme gift of the North American intellectual tradition. And like Marshall McLuhan and Erving Goffman, Peterson was born in Alberta!

GA - In your new book, there is a long interview you gave in 2003 to David Talbot in Salon.com, where you criticize the imminent U.S. invasion of Iraq. At that time, prominent political commentators and editors, some of whom were icons of the Left, such as Christopher Hitchens, David Remnick and Glenn Greenwald, supported the Bush adventure, despite opposition from traditional U.S. partners, such as France, Germany, and Canada. How do you see your position today?

$\mathrm{CP}$ - I consider that interview with David Talbot (the editor-in-chief and co-founder of Salon.com) to be a highlight of my career. I was virtually alone among American political commentators in condemning the invasion of Iraq before it happened, and I believe that my warnings about the disasters that would follow were clearly prophetic.

It must be stressed that I am definitely not anti-military: my father and four of my uncles served in the U.S. Army or Navy during World War Two. Another uncle was an artillery specialist in the New York State National Guard for 30 years. My father's cousin was a pioneering member of the WAVES, the women's unit of the U.S. Naval Reserve during World War Two. My mother's cousin suffered mutilating injuries to his arm and hand from an exploding artillery shell during the Korean War.

The Iraq invasion was launched by naïve and mendacious politicians (notably Vice-President Richard Cheney, who pushed George W. Bush into war) who had never served in the military and who were utterly incompetent in their plans and forecasts. The huge, tragic cost borne by the grievously injured and dead on both the American and Iraqi sides remains unconscionable. I regret that Cheney has paid no price whatever for his sins. He should have been indicted and put on trial for his willful deceptions. 
As for the host of U.S. newspaper editors and star commentators who supported the invasion, they should admit their ignorance and gullibility and hang their heads in shame.

CP - You have collected and studied objects from the first indigenous inhabitants of the area around Philadelphia. Can you tell us something about this activity?

My current research project began a decade ago, after I had been living in the suburbs outside Philadelphia for over 25 years. I was in my first year of work on Glittering Images, my book about art that would be published in 2012. Probably because I was unusually visually attuned at that time, I suddenly began noticing odd groupings of stones in the landscape only a few miles from my house. After close inspection and wider exploration, I became convinced that there are numerous ruined remnants of Stone Age constructions in Southeastern Pennsylvania that have never been identified or catalogued.

Next, I did a great deal of library work at the famous University Museum of the University of Pennsylvania, which has a huge collection of anthropological books about Native Americans, but I found virtually nothing about what I was detecting in the wooded hills around Philadelphia. The standard chronological typology chart for stone projectiles and knives in Pennsylvania shows that the earliest artifacts found here date from 10,000 B.C.- - long before the great pyramids of Egypt! I am particularly interested in the protracted period after the withdrawal of the North American glacier, when Native Americans would have moved into this area as temperatures moderated and hunting grounds expanded.

We know much more about the Native Americans of the Central Plains, Southwest, and Northwest in the U.S. because the camera had been invented by the time the American frontier reached them in the nineteenth century. But the indigenous inhabitants of Southeastern Pennsylvania had left this area and moved west by the late eighteenth century because of the arrival of European settlers, whose farming and fur trade disrupted their hunting grounds. I have been astonished by the amount of Native American material that has been left scattered around this entire region. Now that my perception has been sharpened, I can scarcely walk across a lawn or glance at the edge of a parking lot without finding fragments of stone tools or blades. 
I certainly need to write a book about my discoveries, but I am not sure what exact shape it should take. There is one thing that I am certain about: my focus will be the religious vision of Native Americans, particularly as it relates to the operations of nature.

\section{References}

PAGLIA, Camille. The North American Intellectual Tradition. Interfaces Brasil/Canadá, v. 12, n. 1, p. 201-214, 2012.

. Imagens cintilantes: uma viagem aatravés da arte, desde o Egito a Star Wars. Rio de Janeiro: Apicuri, 2014

. Prefácio. In: AXT, Gunter. Histórias de Vida: mulheres do Direito, mulheres no Ministério Público. Florianópolis: Procuradoria-Geral de Justiça SC, 2015. . Provocations: Collected Essays. New York: Pantheon Books, 2018.

\section{Notes}

${ }^{1}$ Ph.D. Social History (USP), associate researcher at Universidade de São Paulo, SP, Brasil. gunter@terra.com.br 